\title{
POLITENESS STRATEgIES IN WiKI-MEdiATED COMMUNICATION OF EFL COLLABORATIVE WRITING TASKS
}

\author{
Mimi Li \\ University of South Florida; Sichuan Normal University, China
}

\begin{abstract}
Informed by the theory of social constructivism and computer-mediated communication (CMC), wiki-mediated collaborative writing has been increasingly implemented in second or foreign language classes. However, to date, no research has addressed students' interaction and negotiation of their social relationship during wiki-mediated collaboration. Drawing on politeness theory, particularly Brown and Levinson (1987)'s taxonomy of politeness strategies, this study analyzed the wiki-mediated discourse of one collaborative writing group in a Chinese EFL context. This particular writing group consisted of three EFL college students at a southwestern university in China. This article examined specifically how this small group actively engaged in social interaction by adopting politeness strategies during asynchronous communication in a wiki "Discussion" module. Results revealed that this small group used three types of politeness strategies, i.e. positive, negative, and bald on record skillfully, to establish friendship, solidarity and respect while completing their collaborative writing tasks smoothly and efficiently. This study validates the value of linguistic politeness strategies in the analyses of social interaction occurring in computer-mediated discourse and also suggests some pedagogical implications.
\end{abstract}




\section{INTRODUCTION}

With the advancement of educational technology, computer-mediated collaboration has gained popularity in second or foreign language writing classes. During computer-based collaborative writing activity, learners are availed of the opportunity to co-construct knowledge and foster communicative skills in the online community. As Pennington (2003) argued, writing in the computermediated communication (CMC) contexts is moving in the direction of "a more social construction of the activity and interactivity of writing" (p. 304). Ware and Warschauer (2006) added later that "asynchronous discussion formats, in particular, are believed to combine the interactive aspect of written conversations with the reflective nature of composing" (p. 111).

The previous literature (Vinagre, 2008), however, indicated that the collaborative task carried out via asynchronous formats does not necessarily lead to participants' collaboration and learning. The effectiveness of group learning, to a large extent, depends on the appropriate social interaction that takes place among participants (Kreijin, Kirschner, \& Jochems, 2004; Vinagre, 2008). How the group members interact with each other and negotiate their tasks and social relationship in the CMC context, therefore, has a significant impact on their ability to collaborate, to learn, and to ultimately complete a task successfully.

Linguistic politeness has been long regarded as a means to reduce interpersonal friction and to facilitate smooth social interaction (Lakoff, 1973; Leech, 1983). As Park (2008a) posited, linguistic politeness theory is wellpositioned to provide a framework for an analysis of social interaction among participants in both face-to-face and CMC settings. This viewpoint was echoed by other researchers (e.g., Morand \& Ocker, 2003; Vinagre, 2008; Yang et al, 2006). Morand and Ocker (2003) stated that "face-threatening acts" (Brown \& Levinson, 1987) are inevitable in interaction across various CMC channels, just as they are in the face-to-face mode, and therefore, politeness theory can be a useful tool for CMC research. Vinagre (2008) also asserted that politeness influenced the efficiency and effectiveness of computer-mediated interaction. $\mathrm{He}$ reasoned that there are certain barriers in the CMC context which may hinder social interaction, "for example, students may not know each other previously (high social distance) and requests and offers which appear recurrently in collaborative learning messages can threaten the participants' negative face" (p.1022). Also, collaborative learning involves positive interdependence and 
mutual responsibility, both of which could potentially threaten the negative face of participants. Politeness strategies, therefore, seem to "make a unique contribution to the construction of co-operative social interaction" (Watts, 2003, p. 47).

However, despite its relevance, there is a lack of studies examining sociointerpersonal communication in an asynchronous CMC environment. There is also no study applying politeness theoretical framework to the analysis of communication discourse in computer-mediated collaborative writing. Accordingly, I aim to bridge this gap by drawing on politeness theory to analyze and demonstrate how members in a small group negotiate their collaborative writing tasks as well as their social relationships via a wiki "Discussion.".

This paper is part of a larger study (Li \&Zhu, 2011) which explored students' interactions during wiki-mediated collaborative writing in an EFL context and their perceptions of the activity. In the current paper I apply politeness theory to the analysis of wiki-mediated discourse from one small group which demonstrated a harmonious interaction throughout the project, to examine how this particular writing group performed politeness strategies and negotiated their writing tasks via a wiki "Discussion". The specific research question I address is "How does the small group of EFL students use politeness strategies to construct their social interaction and to conduct the collaborative writing task in the wiki space?"

\section{LITERATURE REVIEW}

\section{Wiki-mediated Collaborative Writing}

Informed by social constructivism (Vygotsky, 1978) which views learning as a mediated process of social interaction, collaborative work has been widely implemented in language classes for decades. Due to the development of educational technology, computer-mediated collaborative writing in which a small group of students jointly produces a document with group responsibility for the end product in the online mode is increasingly capturing researchers' attention (e.g., Ducate, Anderson, \& Moreno, 2011; Elola \& Oskoz, 2010; Kessler \& Bikowski, 2010; Kessler, Bikowski, \& Boggs, 2012; Li \& Zhu, 2011).

Wiki, an asynchronous CMC technology, is widely acclaimed as a platform naturally suited for collaborative writing. A wiki is a collaborative web site 
which allows users to freely create and edit the contents of web pages. It has three defining functions. "Edit" allows members to write and revise the page freely; "History" reflects any changes that have been made to the page; "Discussion" enables members to discuss and interact via asynchronous messaging throughout the writing process $(\mathrm{Li}, 2012)$. The affordance of wikis eases the collaborative process, facilitates interactions, and supports the development of student writing (Lee, 2010; Lundin, 2008).

The current body of research has moderately discussed students' revising behaviors in the wiki writing process (Arnold, Ducate, \& Kost, 2012; Kessler \& Bikowski, 2010; Mak \& Coniam, 2008), the wiki writing product in terms of textual or metadiscourse features (Elola \& Oskoz, 2010; Kuteeva, 2011), and student perceptions of wiki-based collaborative writing (Chao \& Lo, 2009; Martinsen \& Miller, 2012; Zorko, 2009). Yet, limited literature (Arnold et al, 2012; Bradley, Linstrom, \& Rystedt, 2010; Li \& Zhu, 2011) has delved into the nature and dynamics of small groups' interactions during wiki-mediated collaborative writing processes, and few have analyzed students' ongoing communication in the form of written discourse posted in the wiki "Discussion" which I believe can provide a great affordance for collaborative writing activities.

Therefore, I am particularly interested in how students in small groups negotiate their collaborative writing tasks and co-construct their social interaction using the wiki "Discussion" module. Park's (2008b) perspective that linguistic politeness theory provides a framework for analyzing social interaction in the CMC context motivated me to examine a small group's communication within a wiki-mediated collaborative writing task by drawing on Brown and Levinson's (1987) taxonomy of politeness strategies.

\section{Politeness in CMC}

Politeness theory has a long history in linguistic research focusing on interaction. This theory originates from the construct of "face" proposed by Goffman (1967). Goffman holds that face is associated with the social-emotional notions of being embarrassed or humiliated, and face can be lost, maintained, or enhanced when people participate in any interpersonal interaction. Brown and Levinson (1987) built on this concept and defined face as "the public self-image that every member wants to claim for himself" (p. 61). Participants attempt to preserve their self-image at the same time as they try not to damage others' image. Brown and Levinson pointed out two interrelated aspects of face desire: 
positive and negative. Positive-face desire is rooted in involvement, connection, and proximity with others, while negative-face desire is realized by giving others options, independence, and freedom from imposition (Brown \& Levinson, 1987). They also delineated four major categories of politeness strategies interlocutors apply to address others' face wants: bald on record, positive politeness, negative politeness, and off-record.

With the emerging interest in politeness theory in the analysis of computermediated discourse, researchers have begun to examine learners' use of politeness strategies while fulfilling collaborative tasks in synchronous and/or asynchronous modes. Yang et al. (2006) highlighted the role of politeness in student participation in an online class discussion. They posited that students used politeness strategies to develop a sense of community in which students felt comfortable exchanging ideas and co-constructing learning in the CMC environment. As they pointed out, "a concern with politeness in discourse is more than simply an additional veneer added to make one's words 'nicer' but instead, seems to be at the core of reflecting how words enact or reflect the relationship between interlocutors in any discourse event" (p.342).

In another CMC study, Vinagre (2008) analyzed how participants in Spain and Ireland interacted during collaborative e-mail exchanges using politeness strategies in an E-tandem project. The findings suggested that partners did not use negative politeness strategies as often as expected in the circumstances where the social distance was high, but they employed positive politeness strategies more often. This observation, in Vinagre's opinion, indicates that fostering closeness, solidarity, and cohesion is the prior task for the partners in this Etandem project. In a K-12 context, Park (2008a, 2008b) examined linguistic politeness and face-work in CMC involving online collaborative math problem solving in a chat forum. He found that students used positive politeness and baldon-record strategies frequently, and the use of off-record rarely occurred. Park (2008b) also identified the time as influencing factor and argued "to compensate for the slowness of keyboarding and to follow the real-time conversational flow, speech participants tend to use direct speech acts" (p. 2202).

The previous literature suggests that effective interpersonal communication via polite strategies is a critical factor in enhancing group involvement and collaboration in a CMC context. As Schallert et al (2009) stated, the politeness conventions address the dynamic social relationships among participants, which leads to the success of online learning. In this paper, I will examine how a small 
group of EFL college students use politeness strategies as they negotiate their collaborative writing tasks via wiki "Discussion".

\section{METHODOLOGY}

\section{Research Approach}

This research adopted a case study approach. A case is a "functioning specific", a system with boundaries (Stake, 1998, p. 87). According to Johnson (1992), a case may be an individual, a class, or a "communicative interaction in a particular situation" (p. 76). The case in the present study is one small group's wiki-mediated interaction, with the discourse on this group's wiki "Discussion" comprising a bounded system.

\section{Site and Participants}

This study was from a larger project carried out in a Wikispaces site (Figure 1) entitled "three heads are better than one". I conducted this study at a large university in southwestern China cross a span of five weeks during summer, 2010. After ethical approval, fifteen Chinese EFL college students at this university were recruited to participate in this study. They were divided into five small groups of three members each. The groups completed a total of three writing tasks via "Wikispaces". Details about the site and data collection procedures can be accessed in Li \& Zhu (2011) where we discuss different patterns of interaction in these small wiki writing groups.

Figure 1: Screenshot of the Wikispaces Site

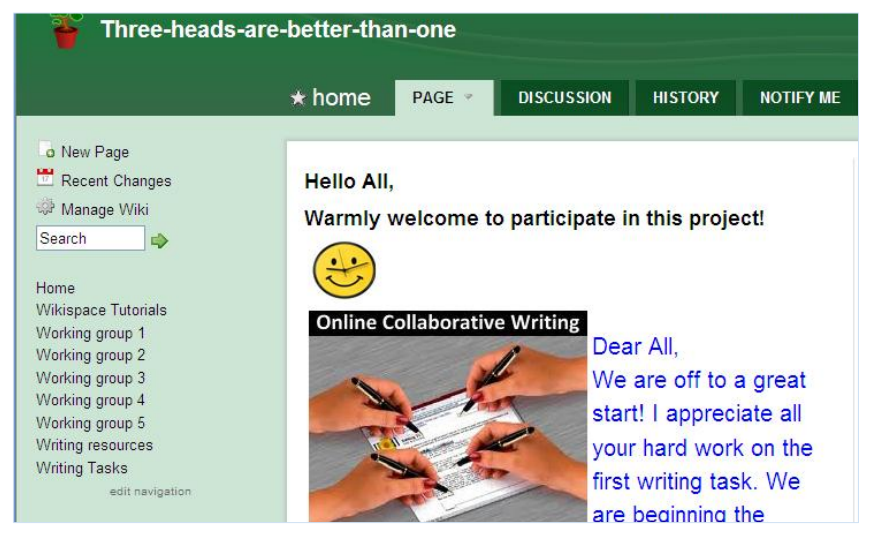


The current study merely focused on one collaborative writing group: Group 1, whose interaction pattern was reported in Li \& Zhu (2011). This group was composed of one male junior named Wang, and two female sophomores named Lin and Zhao (all pseudonyms). The two females were classmates, but they were strangers to Wang. His language proficiency level is intermediate high, while Lin's and Zhao's language proficiency level is intermediate. This group was found to demonstrate an authoritative/responsive pattern of interaction; specifically, Wang played the role of the expert and consistently oriented the joint writing task, and Lin and Zhao acknowledged Wang's authority, both responsive to his ideas (Li \& $\mathrm{Zhu}, 2011$ ).

I purposefully selected this group because the group members, who were not all acquaintances, seemed to collaborate smoothly and effectively throughout this project. Furthermore, in the post-task interviews, the group members voiced very positive learning experiences, particularly addressing the social aspects such as friendship establishment, and continued assistance in study and daily life. I believe the analysis of this small group's wiki-mediated communication through a lens of politeness theory will contribute to our understanding of the role of politeness strategies in collaborative group interaction in the online mode.

\section{Data Source and Data Analysis}

The data in this study were the archived records of a wiki "Discussion" conducted by this small group. The "Discussion" data, reflecting the three group members' communication of three EFL collaborative writing tasks, were recorded as posts automatically on the Wikispaces site. These data allowed me to examine the students' computer-mediated discourse and their interaction process throughout the study. The screenshot of this small group's "Discussion" page is displayed in Figure 2.

A total of 29 posts were tracked from the wiki "Discussion", 15 from Wang, 8 from Lin, and 6 from Zhao. I numbered the 29 discussion posts sequentially. In light of Brown and Levinson's taxonomy of politeness strategies (1987), I identified specific politeness strategies used in the 29 numbered discussion posts and coded them under three general categories of politeness strategies: bald on record $(\mathrm{ON})$, positive politeness $(\mathrm{P}+)$, and negative politeness $(\mathrm{P}-)$ (Off record was not identified in this study). For instance, according to Brown and Levinson's (1987) taxonomy, the thirteen specific strategy "Give (or ask for) reasons" under the category of positive politeness strategy was coded as $\mathrm{P}+13$ in this study. 
Multiple sub-strategies emerged from each post. The detailed coding taxonomy is displayed in Table A through Table $\mathrm{C}$ in the Appendix. Also, I quantified each of the three group member's use of the three types of politeness strategies.

\section{Figure 2: Screenshot of Wiki "Discussion"}

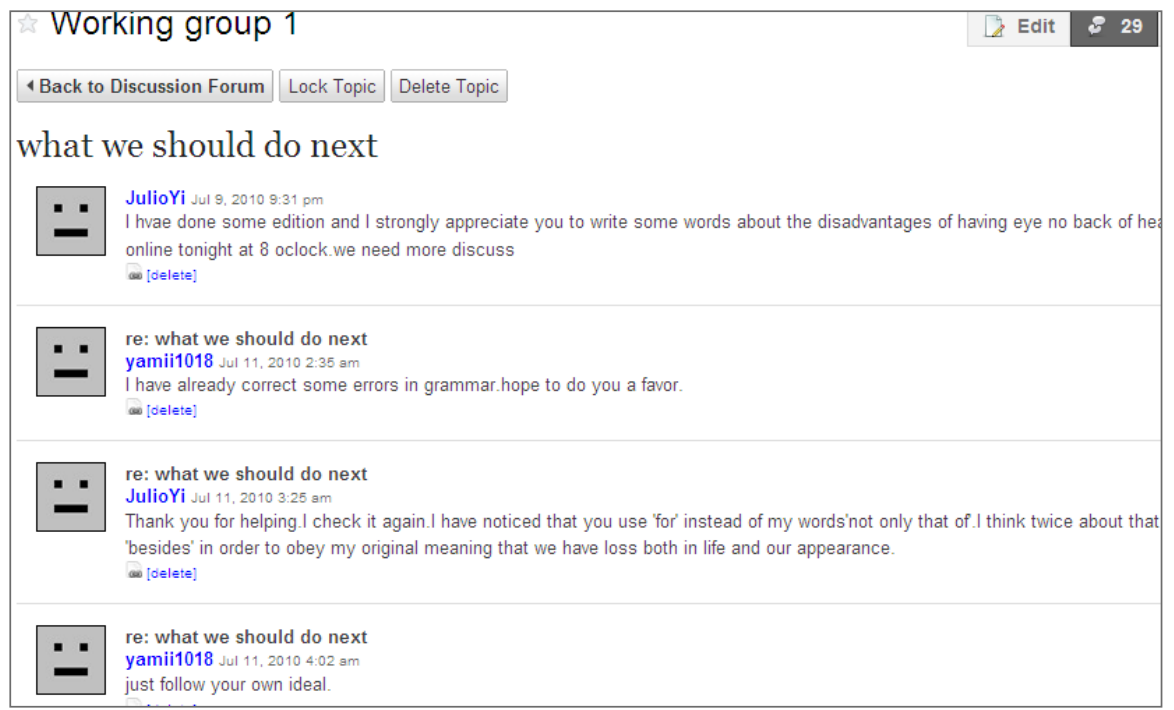

\section{FINDINGS}

The analysis of wiki "Discussion" records in this small group revealed that the group members used three types of politeness strategies to negotiate their writing tasks as well as their interpersonal relationship. This group was involved with a total of 94 instances of specific politeness strategies, including 48 positive politeness strategies $(\mathrm{P}+), 35$ negative politeness strategies $(\mathrm{P}-)$ and 11 bald on record strategies (ON), as is shown in Table 1, Table 2, and Table 3, respectively. The positive strategies were utilized most frequently, accounting for $51 \%$ of the total, followed by the use of negative politeness strategies, accounting for $37 \%$. There were also instances of using bald on record strategies, accounting for $12 \%$.

Specifically, this group demonstrated a variety of positive politeness strategies, attending to group member's desire for positive face when they discussed their collaborative writing tasks via the wiki. As can be seen in Table 1, there were a total of 9 sub-types of positive politeness strategies used, and of these, the most frequently used strategies include: Use in-group identity markers( $\mathrm{P}+4)$, Give gifts (goods, sympathy, cooperation) $(\mathrm{P}+15)$, Give (or ask 
for) reasons $(\mathrm{P}+13)$, and Presuppose/raise/assert common ground $(\mathrm{P}+7)$. The use of varied positive politeness strategy adopted by this group was illustrated with the following representative excerpts.

\section{Excerpt 1:}

25. Lin: Dear partners $(\mathrm{P}+4)$, I really love $(\mathrm{P}+2)$ the message you have sent "last task best ending", which makes me awesome and a little nervous for that we $(\mathrm{P}+4)$ will finish the work (also our baby $(\mathrm{P}+4)).[\ldots]$

This interaction occurred when the group began to work on the third writing task. In this excerpt, Lin used three positive politeness strategies. After their nice collaboration in the previous two tasks, Lin conveyed her strong emotions in a mixture of excitement and concern. She responded to her group member Wang's posting using a positive strategy of Exaggerating interest and approval $(\mathrm{P}+2)$ reflected in her emphatic word choice "really love". Also, she claimed in-group membership by using specific identity marker "partners", and the inclusive "we" $(\mathrm{P}+4)$. Worth noting, she addressed her group members as "dear partners" and referred to their group product as their "baby", which indicated their intimacy and solidarity. Excerpt 2 is the other example.

\section{Excerpt 2:}

\section{Zhao: OK, I'm agree with $(\mathrm{P}+15)$ your standpoint. Let's try} our $(\mathrm{P}+4)$ best $(\mathrm{P}+12)$ to make it $(\mathrm{P}+11)$.

This post revealed that Zhao was responsive to Wang's ideas. When Wang stated that their group writing needed to be largely improved, Zhao immediately echoed him by expressing her agreement $(\mathrm{P}+15)$. She also encouraged the group partners to make united efforts to produce a good essay, by utilizing the In-group identity marker "our" $(\mathrm{P}+4)$, and other strategies of Include both $\mathrm{S}$ and $\mathrm{H}$ in the activity $(\mathrm{P}+11)$ and $\mathrm{Be}$ optimistic $(\mathrm{P}+11)$. All the above tactics that the group members employed contributed to decrease in social distance and accordingly increase social proximity and solidarity among the group members. 
Table 1: Positive Politeness Strategies

\begin{tabular}{|c|c|c|c|c|}
\hline Positive Politeness Strategies & Wang & Lin & Zhao & Total \\
\hline$(P+2)$ : Exaggerate (interest, approval, sympathy) & 1 & 2 & 0 & 3 \\
\hline$(\mathrm{P}+4)$ : Use in-group identity markers & 7 & 7 & 2 & 16 \\
\hline (P+7): Presuppose/raise/assert common ground & 3 & 1 & 1 & 5 \\
\hline$(P+10)$ : Offer, promise & 0 & 1 & 0 & 1 \\
\hline (P+11): Be optimistic & 0 & 1 & 0 & 1 \\
\hline (P+12): Include both $\mathrm{S}$ and $\mathrm{H}$ in the activity & 1 & 0 & 1 & 2 \\
\hline$(\mathrm{P}+13)$ : Give(or ask for) reasons & 4 & 0 & 2 & 6 \\
\hline$(P+14)$ : Assume or assert reciprocity & 1 & 3 & 0 & 4 \\
\hline$(P+15)$ : Give gifts (goods, sympathy, cooperation) & 7 & 1 & 2 & 10 \\
\hline Total & 24 & 16 & 8 & 48 \\
\hline
\end{tabular}

Meanwhile, as shown in Table 2, this group employed various negative politeness strategies, attending to the group members' desire for negative face. The small group was engaged with 8 sub-types of negative politeness strategies and frequently used three strategies: Question, hedge (P-2), and Be conventionally indirect (P-1), and Apologize (P-6). The following excerpts illustrated how Wang used diverse negative politeness strategies to redress his partner's negative-face want.

\section{Excerpt 3:}

14. Wang: Can someone do a formal edition of our work (P-1)? Such as the size of word. I have tried but in vain $(\mathrm{P}+13)$.

Wang expected someone else from his group to edit their work, so he used an indirectly conventional form (P-1) to articulate his request. He then added that it 
$\mathrm{Li}$

was not that he did not want to contribute, but rather that he failed in his own attempt to do so.

Table 2: Negative Politeness Strategies

\begin{tabular}{|c|c|c|c|c|}
\hline Negative politeness strategies & Wang & Lin & Zhao & Total \\
\hline (P-1): Be conventionally indirect & 5 & 0 & 2 & 7 \\
\hline (P-2): Question, hedge & 8 & 2 & 1 & 11 \\
\hline (P-3): Be pessimistic & 0 & 1 & 0 & 1 \\
\hline (P-4): Minimize the imposition & 1 & 1 & 0 & 2 \\
\hline (P-5): Give deference & 2 & 0 & 0 & 2 \\
\hline (P-6): Apologize & 2 & 3 & 2 & 7 \\
\hline $\begin{array}{l}\text { (P-7): Impersonalize S and H:avoid } \\
\text { you }\end{array}$ & 0 & 2 & 0 & 2 \\
\hline $\begin{array}{l}\text { (P-10): Go on record as incurring a debt, } \\
\text { or as not indebting } \mathrm{H} \text {. }\end{array}$ & 3 & 0 & 0 & 3 \\
\hline Total & 21 & 9 & 5 & 35 \\
\hline
\end{tabular}

It is also found that Wang used quite a few hedges (P-2) as shown in the following example.

\section{Excerpt 4:}

4. Zhao: but I find the edit is out of use. Can you tell me what is wrong?

5. Wang: I haven't met with that problem. But I think (P-2) the reason maybe (P-2) your internet explorer need update.

Zhao turned to her group partners and sought technological help. Wang responded to her by using hedges such as 'I think' and 'maybe', indicating that he did not want to presume and he was not taking full responsibility for the truth of his utterance, thus saving both $\mathrm{S}$ and H's faces. 
Moreover, there are quite a few occurrences of Give deference (P-5) in this group's interaction, as presented in Excerpt 5.

\section{Excerpt 5:}

16. Wang: sorry, it is my fault (P-6). You are right. I should have been more serious. (P-5) Sorry again (P-6).

This excerpt occurred after Wang's partner Zhao pointed out that he mistakenly revised a phrase she used. Wang used the strategy of apologize (P-6) and by saying "sorry, it is my fault", and "sorry again", he acknowledged his own fault and humbled himself by indicating he was not serious when doing revision.

Furthermore, the circumstances of the use of bald on record strategy (presented in Table 3) were identified, what Brown and Levinson (1987) called non-minimization of the face threat: "Where efficiency is very important, and this is mutually known to both $\mathrm{S}$ and $\mathrm{H}$, no face redress is necessary. In cases of great urgency or desperation, redress would actually decrease the communicated urgency." (p. 95-96). For instance, when the deadline of collaborative writing task was approaching, Wang used bald on record strategy very skillfully to reinforce the urgency of the writing task so as to facilitate group's efficient work. Excerpt 6 is illustrative.

\section{Excerpt 6:}

2. Wang: Hi everyone, $(\mathrm{P}+4)$ In my opinion ( $\mathrm{P}-2)$, our have-done jobs seem just like a patchwork, not a real essay. Each part is too independent $(\mathrm{P}+13)$. So I would like $(\mathrm{P}-1)$ to integrate they into a formal article. Do you mind (P-5) my editing? Please reply me immediately $(\mathrm{ON})$ ! Time is running out $(\mathrm{P}+13)$. Thank you...( $(\mathrm{P}+15)$

Wang used a variety of strategies to call his partner's attention to this deadline. The approach of due date demanded a direct, clear, and brief style, that illustrated why Wang used the bald on record strategy. However, he combined the use of bald on record strategy with the positive politeness strategy. He used give reasons $(\mathrm{P}+13)$ and give gifts $(\mathrm{P}+15)$ to mitigate and soften the force of the direct request. The acknowledgement utterance redressed the illocutionary force of the direct speech act and therefore contributed to satisfying group members' positive or negative face desire. 
Table 3: Bald on Record Strategy

\begin{tabular}{|lllll|}
\hline & Wang & Lin & Zhao & Total \\
\hline $\begin{array}{l}\text { Cases of non- } \\
\text { minimization of } \\
\text { the face threat }\end{array}$ & 9 & 1 & 1 & 11 \\
\hline
\end{tabular}

Taken together, this small group used combined politeness strategies appropriately when they posted their thoughts and negotiated on their collaborative writing tasks. Excerpt 7 shows Lin's skillful use of the three different types of polite strategies.

\section{Excerpt 7:}

19. Lin: I am sorry (P-6) to have caused trouble to you two. But I can get online smoothly now. I think (P-2) I could help u $(\mathrm{P}+4)$. And I have added some details on the task $(\mathrm{P}+14)$. But I need u $(\mathrm{P}+4)(\mathrm{ON})$ to completed more examples $(\mathrm{P}+14)$ on the passage which is about "art", such as the functions and the values, thank you $(\mathrm{P}+15)$.

In this excerpt, Lin first apologized (P-6) for her temporary absence because of her broken network, and by using a Hedge (I think, P-2), she politely conveyed that she had compensated for some work. Then she directly claiming the reciprocal obligation $(\mathrm{P}+14)$ : she just added details on the task for the group, and now it is their group members' turn to write more examples for the group work. Under this circumstance, Lin indicated that group members are cooperators, and everyone needs to contribute to the group writing. As Wang did, Lin employed a bald on record strategy with the structure of "I need u", and later she redressed this direct speech act immediately by using positive politeness strategy to fulfill H's wants, i.e. giving her thankfulness to her partners $(\mathrm{P}+15)$. Also worth noting, she employed informal speech style, i.e. contraction ' $u$ ' twice to build rapport and reinforce familiarity.

Comparing all the strategies demonstrated by different group members, I discovered that some strategies were exclusive to particular individuals. Only Zhao used Avoid disagreement $(\mathrm{P}+6)$; only Lin employed Offer, promise $(\mathrm{P}+10)$, Be optimistic $(\mathrm{P}+11)$, Be pessimistic (P-3), Impersonalize $\mathrm{S}$ and $\mathrm{H}(\mathrm{P}-7)$; Wang 
is the only person to use Give deference (P-5), Go on record as incurring a debt, or as not indebting $\mathrm{H}$ (P-10). Also, there was much more asynchronous communication between Wang and either of the two females than the communication between the two females per se. Despite the difference of the individual member's employment of specific politeness strategies, the three members drew on the varied politeness strategies and negotiated their writing tasks in quite a harmonious and effective manner.

Interestingly, the group members used familiar address to presuppose /raise/assert common ground $(\mathrm{P}+7)$. These familiar addresses in form of member's first name, or the combination of "dear" and first name became evident after they worked on the second task via the wiki. The evolving use of ingroup identity markers, especially the endearment address forms vividly reflected the gradual formation of the group's close social relationship, as shown in Excerpt 8.

\section{Excerpt 8:}

17. Wang: Yan Zhao (pseudonym), I really appreciate your havedone work, [...] PS: Xi Lin (pseudonym) is being hit by typhoon. So it's relatively inconvenient for her to get online. [...]

22. Wang: Xi, $[\ldots]$

23. Wang: Dears, $[\ldots]$

25. Lin: Dear partners, $[\ldots]$

26. Wang: Dear Xi, $[\ldots]$

29. Lin: Dear Long (pseudonym), [...]

During writing task 1, group members used zero addressees or full name (e.g., Yan Zhao, Xi Lin) in their posting. Toward the middle of the second task, they began to use the first name (e.g., Xi) or "dears" to address the partners, and later, the address form evolved to "dear" plus the first name (e.g., dear Xi, dear Long), which is usually reserved for intimates. The change from the use of full name or no addressing during Task 1 to the use of endearment terms or the first name during Task 2 and Task 3 has implied the ongoing process of this group's establishing familiarity and friendliness.

\section{DISCUSSION}

The findings showed that this small group used three types of politeness strategies appropriately to establish positive social interaction and negotiate their 
collaborative writing in the wiki "Discussion" successfully. The three group members, as interpersonally successful cooperators, combined positive politeness strategies and negative politeness strategies or aligned positive strategies with bald on record strategies skillfully during their asynchronous communication via the wiki.

In this study, Wang had the highest word count in wiki "Discussion" posts, and thereafter had the most instances of the use of all three types of politeness strategies, followed by Lin and Zhao. As noted in the earlier discussion, Wang assumed the leader of this group; he more often initiated discussion topics and invited his partners' participation and response. Also, Wang used much more negative politeness strategies and bald on record strategies than his group partners. This observation was possibly related to the authoritative/responsive pattern of interaction that the group demonstrated throughout the study, as was discussed in Li \&Zhu (2011). Wang, playing a role of leader, tended to direct the task orientation using bald on record strategies in the form of requests and requirements, especially when due date for each writing task was approaching. The use of the bald on record strategies led to the group members' high attention to the writing task and active engagement in the revisions at the final writing stage.

This finding reinforced the role of bald on record strategy in CMC collaboration. As researchers (Morand \& Ocker, 2003; Vinagre, 2008) posited, two primary principles of communicative competence, i.e., make oneself clear and be polite, may contradict themselves in the CMC context, since politeness usually entails ambiguous or indirect communication. Therefore, participants sometimes need to subordinate the rule of politeness to that of clarity. When the due date approached, the group's interaction took on a more urgent tone. All the group members, at some point, wrote messages that included direct speech acts. That is, pressure of time was found to be an influencing factor for this group member's strategy use. Along the same lines as Park (2008a, 2008b), the bald on record strategy was used, for the sake of efficiency, to elicit participants' quick response, which was for their mutual benefits. However, the study revealed that the direct speech acts never occurred singularly; they were sequenced often with politeness strategies within the same post. In this way, the group members performed their wiki-mediated interaction both politely and effectively. They achieved solidarity, group trust and respect, and cohesiveness via different types of politeness strategies in the $\mathrm{CMC}$ context. 
Interestingly, Wang was authoritative without necessarily being authoritarian (van Lier, 1996). He actively involved his two female partners in the interactions and showed respect and deference to them. He used a number of negative politeness strategies., As the group leader, Wang oriented the writing directions, which may impinge on others' negative face, so he used numerous negative politeness strategies to soften the weight of imposition. Also, the study revealed that there was much more asynchronous communication between him and either of the two females than the communication between the two females per se. This phenomenon may result from the fact that the two females are good friends. They might discuss their writing via other channels, e.g., face-to-face meeting, phone call, or synchronous chatting tool.

In terms of the group familiarity, the two female sophomores Lin and Zhao, being classmates, had known each other; however, both of them were strangers to the male junior, Wang. Accordingly, there was some social distance among the group members. According to Brown and Levinson (1987), speakers tend to use negative politeness strategies more often than the positive politeness strategies when they are distant in social relations. My findings, however, cannot support this proposition fully. This group started on a friendly footing, and used many positive politeness strategies to satisfy group members' positive face desire, reflected from their claiming common ground, conveying that $\mathrm{S}$ and $\mathrm{H}$ are cooperators, and fulfilling H's want. The phenomena possibly resulted from the nature of the collaborative work. In wiki-mediated collaborative writing, group members, as co-authors, have joint responsibilities for the writing product. Establishing friendship and solidarity, therefore, is critical for their collaborative writing task. The presence of high percentage of positive politeness in their wiki discussion indicated that group members tried to build reciprocity, mutual cooperation, and sense of community. This small group's frequent use of politeness strategies in asynchronous $\mathrm{CMC}$ was in line with the findings in Park (2008) in which students liked to use positive politeness strategies during collaborating on online tasks even when they were not acquaintances with each other.

In addition, the evolving process of this group's positive social relationship can be reflected from the in-group identity markers, especially the address forms that the group members used throughout the project. The utilization of familiar address forms presupposes familiarity in $\mathrm{S} / \mathrm{H}$ relationship; this is especially the case in Chinese culture. In the Chinese context, the full name is commonly used in the public place (e.g., in the classroom), and the first name is the endeared form of address, which is often used among friends or direct relatives. "Dear" is 
seldom used between males and females unless they have a close relationship, and "dear" plus the first name definitely shows intimacy. This finding showed that the group members demonstrated a closer social relationship as the collaborative writing task went on. The CMC setting afforded the group members to apply the endearment form when addressing the partner of a different gender, which they may feel embarrassed to do in a face-to-face setting. The strategy of In-group identity marker, especially the familiar address forms, helped this group establish friendship and facilitate their collaborative interaction, which contributed to the maintaining of a positive interpersonal relationship, in turn "engendering a positive atmosphere for furthering involvement and collaboration among group members.” (Park, 2008, p. 2205)

\section{Limitations And Pedagogical Implications}

This study focused on a case of EFL collaborative writing group and explored how the group members used politeness strategies to negotiate their social relationships and to facilitate collaborative writing via a wiki "Discussion" by using politeness strategies. The findings suggested that the use of politeness strategies leads to strategic construction of co-operative social interaction (Watts, 2003). The group members used a variety of positive politeness strategies to show the solidarity and friendship, and meanwhile they used quite a few negative politeness strategies to show respect and deference to one another. When they were pressed for time, they used bald on record strategies to facilitate the efficiency of the collaborative work. This study validates that "linguistic politeness theory provides a framework for an analysis of social interaction undertaken through online discussion forums" (Park, 2008, p. 2208).

However, this study merely examined one small group's asynchronous messaging in a wiki "Discussion," and the computer-mediated discourse consisted of a total of only 29 posts. Therefore, the scope of this study is small, and the analysis of more cases in the same context would lead to more perspectives and better interpretation of the dynamics of group interaction in terms of group members' politeness strategy use. Further research could continue to examine the role of politeness strategy in the analyses of CMC discourse in larger sample size. The exploration of politeness strategy use in other groups and the comparison among groups, via collective case study, will contribute to our better knowledge of the social interaction during wiki-mediated collaborative writing. Also, the use of politeness strategies in other CMC genres or in other learning contexts will deserve careful investigation. Further research could also 
explore what factors influence the students' strategy use during collaborative writing in the CMC context. In addition, a longitudinal study, addressing the connection between students' social interaction and their learning outcomes would provide insights into the relational aspects of collaborative learning.

Despite the limitations, this study has some important pedagogical implications. First, a wiki is a great platform for collaborative writing due to its distinctive functions, including editability, detailed page history, and asynchronous discussion. The wiki "Discussion" module enables students to discuss the collaborative writing task at their own time and pace while negotiating their social relationship, especially when the social distance occurs among the group members. Teachers need to take advantage of the different functions of wiki technology to implement collaborative writing in second or foreign language classes. Previous research (e.g., Bradley et al, 2010; Kessler \& Bikowski, 2010; Lee, 2010) indicated that teachers and researchers attend to wiki "Page" and "Edit" functions on most occasions, but ignore the pedagogical use of the wiki "Discussion" function. Therefore, I point to the need for teachers/practitioners to incorporate the use of the wiki "Discussion" into their wiki-based collaborative writing project. Students need to be trained specifically how to make full use of the wiki "Discussion" module. For example, in the larger project (Li \& Zhu, 2011), students were instructed to exchange ideas on "Discussion" before or during constructing texts on "Page", and to post rationales for textual changes after revising or editing texts. The students were found to be highly engaged with content discussion, social talk, task management, technical communication, and language-related episodes.

Secondly, this study found that the small group effectively used diverse politeness strategies in the asynchronous wiki "Discussion" in order to conduct their collaborative writing task smoothly. This finding revealed that the wiki can serve as a platform for students not only to practice EFL writing, but also to practice their linguistic and pragmatic knowledge in an authentic communication and learning environment. The finding echoes Chen (2005)'s perspective that the integration of CMC into EFL learning can allow learners to gain more authentic input and help facilitate students' linguistic and pragmatic knowledge. Regarding the collaborative group work in the CMC environment, teachers may instruct the students about the pragmatic conventions during training sessions and alert them to use different types of politeness strategies appropriately in the collaborative writing task, so that students will be able to establish solidarity and mutual understanding, communicate effectively, and jointly facilitate learning in the collaborative writing activity. In other words, teachers are encouraged to link the 
$\mathrm{Li}$

training of students writing skills and training of their communicative/intercultural competence, such as teaching pragmatic knowledge and raising students' pragmatic awareness through computer-mediated collaborative work.

In addition, teachers need to take group structures into account when implementing wiki-mediated collaborative writing. It is recommended that teachers limit the group size to three or four, because a group consisting of three or four members is found to work most successfully, while larger groups are likely to have one or more members who participate at a reduced level (Morgan, Allen, Moore, et al, 1987) or who are called "social loafer" or "free rider" (Piezon \& Donaldson, 2005). Also, group members' language proficiency and gender need to be considered. As this study suggested, teachers may form students of different genders into one group, and the group members' language proficiency can be mixed, but not all are at relatively low level. However, since this study is small in scope, this implication is premature, and it deserves deeper examination in future studies.

\section{ACKNOWLEDGEMENTS}

I would like to convey my deep gratitude to Dr. Wei Zhu for her guidance and encouragement throughout the study. I am also very grateful to Dr. Camilla Vasquez for her detailed constructive feedback on the earliest version of this article. My appreciation also goes to the IALLT Journal editor Dr. Dan Soneson and the anonymous reviewers for their valuable and insightful feedback. 


\begin{abstract}
About the Author
Mimi Li is a Ph.D. candidate in Second Language Acquisition/ Instructional Technology at the University of South Florida, USA, as well as a College English lecturer at Sichuan Normal University in China. Her research interests include computer-assisted language learning, second language writing, interlanguage pragmatics, and English for academic/specific purposes. Her work has appeared in journals such as Computer Assisted Language Learning, CALLEJ, and Asian ESP Journal.
\end{abstract}




\section{REFERENCES}

Arnold, N., Ducate, L., \& Kost, C. (2012). Collaboration or cooperation? Analyzing group dynamics and revision process in wikis. CALICO Journal, 29 (3), 431-448.

Bradley, L., Linstrom, B., \& Rystedt, H. (2010). Rationalities of collaboration for language learning in a wiki. ReCALL, 22(2), 247-265.

Brown, P., \& Levinson, S.C. (1987). Politeness: Some universals in language usage. Cambridge, UK: Cambridge University Press.

Chao, Y., \& Lo, H. (2009). Students' perceptions of wiki-based collaborative writing for learners of English as a foreign language. Interactive Learning Environments, 2009. Retrieved from http://dx.doi.org/10.1080/10494820903298662

Chen, Y. (2005). Computer-mediated communication: the use of CMC to develop EFL learners' communicative competence. Asian EFL journal $7(1), 167-182$.

Ducate, L., Anderson, L., \& Moreno, N. (2011). Wading through the world of wikis: An analysis of three wiki projects. Foreign Language Annals, 44 (3), 495-524.

Elola, I., \& Oskoz, A. (2010). Collaborative writing: Fostering foreign language and writing conventions development. Language Learning \& Technology, 14 (3), 51-71.

Goffman, E. (1967). Interactional ritual: Essays on face-to-face behaviors. Garden city, New York: Anchor Books.

Johnson, D. (1992). Approaches to research in second language learning. New York: Longman.

Kessler, G. (2009). Student-initiated attention to form in wiki-based collaborative writing. Language learning and technology, 7 (2), 12-16.

Kessler, G., \& Bikowski, D. (2010). Developing collaborative autonomous learning abilities in computer mediated language learning: attention to meaning among students in wiki space. Computer-Assisted Language Learning,23 (1), 41-58. 
Kessler, G., Bikowski, D., \& Boggs, J. (2012). Collaborative writing among second language learners in academic web-based projects. Language Learning \& Technology, 16 (1), 91-109. Retrieved from http://1t.msu.edu/issues/february2012/kesslerbikowskiboggs.pdf

Kreijns, K., Kirschner, P., Jochems, W. et. al., (2004). Determining sociability, social space, and social presence in (a)synchronous collaborative groups. Cyberpsychology and Behaviour, 7(2), 155-172.

Kuteeva, M. (2011). Wikis and academic writing: Changing the writer-reader relationship. English for Specific Purposes,30, 44-57.

Lakoff, R. (1973). The logic of politeness, or minding your p's and q's. Chicago Linguistics Society 9, 292-305.

Leech, G. N. (1983). Principles of pragmatics. London, United Kingdom: Longman.

Lee, L. (2010). Exploring wiki-mediated collaborative writing: a case study in an elementary Spanish course. CALICO Journal, 27(2), 260-276.

Li, M. (2012). Use of wikis in second/foreign language classes, A literature review. CALL-EJ 13(1), 17-35.

Li, M., \& Zhu, W. (2011). Patterns of computer-mediated interaction in EFL collaborative writing groups using wikis. ComputerAssisted Language Learning (i-first available).

Lundin, R.W. (2008).Teaching with wikis: Toward a networked pedagogy. Computers and Composition, 25, 432-448.

Mak, B., \& Coniam, D.(2008). Using wikis to enhance and develop writing skills among secondary school students in Hong Kong. System, 36, 437-455.

Martinsen, R., \& Miller, A. (2012). Collaboration through wiki and paper compositions in foreign language classes. The IALLT Journal, 42 (1), 72-95.

Morand, D.A., \& Ocker, R. J. (2003) Politeness theory and computer-mediated communication: A sociolinguistic approach to analyzing relational messages. Proceedings of the 36th Hawaii international conference on system sciences (HICSS-36). Retrieved from 
$\mathrm{Li}$

http://csdl2.computer.org/comp/proceedings/hicss/2003/1874/01/187410 017b.pdf

Morgan, M., Allen, N., Moore, T., et al. (1987). Collaborative writing in the classroom. Bulletin of the association for business communication, 50 (3), 20-26.

Park, J. R. (2008a). Linguistic politeness and face-work in computer mediated communication, Part 1: A theoretical framework. Journal of the American Society for Information Science and Technology, 59(13), 2051-2059.

Park, J. R. (2008b). Linguistic politeness and face-work in computer mediated communication, Part 2: An application of the theoretical framework. Journal of the American Society for Information Science and Technology, 59(14), 2199-2209.

Pennington, M. (2003). The impact of the computer in second language writing. In B. Kroll (Ed.), Exploring the dynamics of second language writing (pp. 287-310). New York: Cambridge University Press.

Pierzon, S., \& Donaldson, R. (2005). Online groups and social loafing: Understanding student- group interactions. Online Journal of Distance Learning Administration, 8(4). Retrieved from http://www.westga.edu/ distance/ojdla/winter84/piezon84.htm

Schallert, D. L., Chiang, Y. V., Park, Y., et al. (2009). Being polite while fulfilling different discourse functions in online classroom discussions. Computers \& Education. Retrieve from doi: 10.1016/j. compedu.2009.04.009.

Stake, R. (1998). Case studies. In N.K. Denzin, \& Y. S. Lincoln (eds.), Strategies of qualitative inquiry. Thousand Oaks, CA: Sage Publications, 86-109.

van Lier, L. (1996). Interaction in the language curriculum: awareness, autonomy and authenticity. London: Longman.

Vinagre, M. (2008). Politeness strategies in collaborative e-mail exchanges. Computers \& Education 50, 1022-1036.

Vygotsky, L.S. (1978). Mind in society: The development of higher psychological processes. Cambridge, MA: Harvard University Press. 
Ware, P., \& Warschauer, M. (2006). Electronic feedback and second language writing. In K. Hyland \& F. Hyland (Eds.), Feedback in ESL writing: Context and issues (pp. 105-122). New York: Cambridge University Press.

Watts, R.J. (2003). Politeness. Cambridge, UK: Cambridge University Press.

Yang, M., Chen, Y., Kim, M., Chang, Y., Cheng, A., Park, Y., et al. (2006). Facilitating or limiting? The role of politeness in how students participate in an online classroom discussion. Yearbook of the National Reading Conference, 55, 341-356.

Zorko, V. (2009). Factors affecting the way students collaborate in a wiki for English language learning. Australasian Journal of Educational Technology, 25 (5), 645-665. 


\section{APPENDiX}

Table A: Positive Politeness Strategies

Strategy Example

Claim common ground

Convey $X$ is admirable, interesting

$(\mathrm{P}+2)$ : Exaggerate (interest, approval, Wow! I really appreciate your work. sympathy with $\mathrm{H}$ )

Claim in-group membership with $H$

$(\mathrm{P}+4)$ : Use in-group identity marker Dear partners,...

Claim common (points of view, opinions,

attitudes, knowledge)

$(\mathrm{P}+7)$ : Presuppose/raise/assert common

ground

Convey that $S$ and $H$ are cooperators

Our have-done jobs seem just like a

patchwork, not a real essay

Claim reflexity

$(\mathrm{P}+10)$ : Offer, promise

I add some sentences to fulfill our assignments.

$(\mathrm{P}+11):$ Be optimistic

May we can finish it better!

$(\mathrm{P}+12)$ : Include both $\mathrm{S}$ and $\mathrm{H}$ in the

Let's try out best to make it. activity

$(\mathrm{P}+13)$ : Give (or ask for ) reasons

I have tried but in vain.

Claim reciprocity

$(\mathrm{P}+14)$ : Assume or assert reciprocity $\quad$ I have add some details on the task.

But I need $u$ to complete more

examples...

\section{Fulfill H's want (for some $X$ )}

$(\mathrm{P}+15)$ : Give gifts to $\mathrm{H}$ (goods,

Thank you.

sympathy, understanding, cooperation)

Adapted from Brown and Levinson (1987)

Examples are the original posts on wiki "discussion". 
Politeness Strategies...

Table B: Negative Politeness Strategies

\begin{tabular}{|c|c|}
\hline Strategy & Example \\
\hline $\begin{array}{l}\text { Be indirect } \\
(\mathrm{P}-1): \text { Be conventionally indirect }\end{array}$ & Can you tell me what is wrong? \\
\hline $\begin{array}{l}\text { Don't presume/assume } \\
\text { (P-2): Question, hedge }\end{array}$ & $\begin{array}{l}\text { I think we can probably set it as a primary } \\
\text { outline... }\end{array}$ \\
\hline $\begin{array}{l}\text { Don't coerce } \mathbf{H} \\
\text { (P-3): Be pessimistic }\end{array}$ & I hope you could add more to it. \\
\hline (P-4): Minimize the imposition & By the way, I strongly advise you... \\
\hline (P-5): Give deference & I should have been more serious. \\
\hline $\begin{array}{l}\text { Communicate S's want to not impinge } \\
\text { on } \mathbf{H} \\
\text { (P-6): Apologize }\end{array}$ & I am sorry to have caused trouble... \\
\hline $\begin{array}{l}\text { (P-7): Impersonalize S and H: avoid "I" } \\
\text { and "you" }\end{array}$ & Where we can indicate it's last year? \\
\hline $\begin{array}{l}\text { Redress other wants of H's, derivative } \\
\text { from negative face } \\
\text { (P-10): Go on record as incurring a debt, } \\
\text { or as not indebting H }\end{array}$ & $\begin{array}{l}\text { I'd like to extend my appreciation if you } \\
\text { are so kind to ... }\end{array}$ \\
\hline
\end{tabular}

Adapted from Brown and Levinson (1987)

Examples are the original posts on wiki "discussion".

Table C: Bald on Record

\begin{tabular}{ll}
\hline Strategy & Example \\
\hline $\begin{array}{l}\text { Cases of non-minimization of the face } \\
\text { threat }\end{array}$ & $\begin{array}{l}\text { Keep you online tonight at } 8 \\
\text { o'clock. }\end{array}$
\end{tabular}

Adapted from Brown and Levinson (1987) 